\title{
TRANSFER OF IN VITRO SYNTHESIZED BARLEY ENDOSPERM PROTEINS INTO THE LUMEN OF THE ENDOPLASMIC RETICULUM
}

\author{
by \\ VERENA CAMERON-MILLS, JOHN INGVERSEN and ANDERS BRANDT \\ Department of Physiology, Carlsberg Laboratory, \\ Gamle Carlsberg Vej 10, DK-2500 Copenhagen, Valby
}

Keywords: Microsomes, hordeins, prolamin, membrane transport

\begin{abstract}
Microsomes were prepared from 20 day old Bomi barley endosperm by sucrose density gradient centrifugation. Electron microscopy revealed the presence of ribosome-studded vesicles in the material banding at the 1.75-2.26 $M$ sucrose interface. The isolated microsomes were active in the wheat-germ cell-free protein synthesizing system. Hordeins were present among the in vitro synthesized products and were identified by their solubility in $55 \%$ isopropanol and by their co-migration with native hordeins on SDS-polyacrylamide gels. The microsomeand polysome-directed, in vitro synthesized hordeins were analysed before and after chymotrypsin treatment by SDS-polyacrylamide gel electrophoresis. The hordeins were degraded when polysomes were used as a template. However, hordeins synthesized on microsomes showed significant protection from proteolysis. This protection could be abolished by treatment with membrane-solubilizing detergents. The reported experiments show that hordeins synthesized on microsomes were discharged vectorially into the lumen of the microsomes.
\end{abstract}

\section{INTRODUCTION}

A characteristic feature of endosperm development in cereal grains is the synthesis of hydrophobic storage proteins, which may comprise as much as $50 \%$ of the proteins present in the mature grain. Electron microscopy of endosperm tissue has revealed that the storage proteins are located in protein bodies, and zeinand hordein-rich bodies have been isolated and characterized from maize and barley respectively $(7,11)$. Techniques for the in vitro synthesis of proteins have recently been exploited in the synthesis of various plant proteins and in particular the storage proteins, zein (13), hordein (4) and oat globulin (14). Bearing in mind the hydrophobic nature of many plant storage proteins and their confinement to membrane-bound vacuoles, it is significant that the main polysome fractions active in storage protein synthesis are found among the membrane-bound polysomes $(4,6,13)$.

The synthesis and transport of proteins has become a subject of considerable interest, particularly in animal cells. Some proteins are transferred from the site of synthesis into intracellular organelles e.g. lysosomes, perox- 
isomes and mitochondria, whereas other proteins such as hormones and immunoglobulins are excreted. It appears to be a general phenomenon that excreted proteins are synthesized on membrane-bound polysomes $(1,5$, 18). The problems associated with transporting proteins across semi-permeable membranes have led to the hypothesis that proteins synthesized on membrane-bound polysomes are transferred across the membrane prior to the release of the nascent chain and assumption of its secondary and tertiary structure with the aid of a signal sequence of amino acids (1). The latter is then removed by site specific proteolysis.

Techniques to demonstrate the concurrent synthesis and transport of proteins in vitro in animal systems $(1,2,12)$ have been utilized for the study of hordein synthesis in barley endosperm. Rough microsomes have been prepared, characterized and the in vitro synthesis of hordeins and their subsequent vectorial discharge into the microsomal lumen demonstrated.

\section{MATERIALS AND METHODS}

\subsection{Chemicals}

HEPES, ATP (disodium salt), GTP (sodium salt), creatine phosphate (disodium salt), creatine kinase (E. C. No. 2.7.3.2.), DTT, spermidine phosphate, $\alpha$ chymotrypsin and L-amino acids were purchased from Sigma Chemicals. $\left({ }^{35} \mathrm{~S}\right)$-Methionine (specific activity approx. 900 $\mathrm{mCi} / \mathrm{mmole}$ ) was obtained from Radiochemical Center, Amersham, U.K.

HKM buffer A $20 \mathrm{~mm}$ HEPES, pH 7.6, $100 \mathrm{~mm}$ -

$\mathrm{K}$ acetate, $50 \mathrm{mM}-\mathrm{Mg}$ acetate, $0.2 \mathrm{M}$-sucrose and $2 \mathrm{mM}$-DTT

HKM buffer B $20 \mathrm{mM}$ HEPES, pH 7.6, $100 \mathrm{~m} \mathrm{M-}$

$\mathrm{K}$ acetate, $5 \mathrm{mM}-\mathrm{Mg}$ acetate and $2 \mathrm{mM}$-DTT

\subsection{Plant material}

Barley plants (Hordeum vulgare L.) cv. Bomi were grown in pots in a growth chamber under a diurnal cycle of $16 \mathrm{~h}$ light, $16^{\circ} \mathrm{C}$, and $8 \mathrm{~h}$ dark, $12^{\circ} \mathrm{C}$ at $65 \%$ relative humidity. Spikes were harvested 20 days after anthesis.

Fresh commercial wheat-germ was obtained from Ringsted Dampmølle, Denmark, and stored in polyethylene bags at $-70^{\circ} \mathrm{C}$.

\subsection{Rough microsome preparation}

Rough microsomes were prepared from 20 day old Bomi barley endosperm by a procedure adapted from that of BLOBEL and DOBBERSTEIN (1). Endosperms were squeezed out from 10-15 freshly harvested spikes and ground to a powder with a mortar cooled with liquid nitrogen. The ground endosperms were suspended in $20 \mathrm{ml} \mathrm{HKM}$ buffer $\mathrm{A}$, and all subsequent operations were performed at $2-4^{\circ} \mathrm{C}$. The suspensions were further homogenized three times for 30 seconds in a Potter-Elvehjem homogenizer operated at $3250 \mathrm{rpm}$. The homogenates were centrifuged at $500 \mathrm{~g}$ for 10 $\mathrm{min}$ in a Sorvall SS-34 rotor, to remove most of the starch, cell walls and unbroken cells. The supernatants were then centrifuged at $37,000 \mathrm{~g}$ for $10 \mathrm{~min}$ to pellet the rough endoplasmic reticulum. The pellets also served as a starting material for detached polysome preparation (section 2.4.).

Rough microsomes were prepared from the $37,000 \mathrm{~g}$ pellets by resuspension in $10 \mathrm{ml}$ of 2.26 $\mathrm{M}$-sucrose and flotation in a discontinuous gradient consisting of $10 \mathrm{ml}$ portions of 1.75 , 1.50 and $0.20 \mathrm{M}$-sucrose, all solutions made up in HKM buffer B. After centrifugation at $96,000 \mathrm{~g}_{\mathrm{av}}$ for $16 \mathrm{~h}$ on a Beckman SW 27 rotor two bands were obtained, one at the $1.75-2.26 \mathrm{M}$ interface (band I) and one at the 1.50-1.75 $\mathrm{M}$ interface (band II). They were both removed with a hypodermic syringe and diluted with an equal volume of HKM buffer $B$. The isolates were further purified by layering $7 \mathrm{ml}$ of suspension on top of a $1.3 \mathrm{M}$-sucrose (in HKM buffer B) cushion and centrifuging at $165,000 \mathrm{~g}_{\mathrm{av}}$ for $1 \mathrm{~h}$ in a Beckman $50 \mathrm{Ti}$ rotor. The pellets were suspended in $0.2 \mathrm{M}$-sucrose HKM buffer $\mathrm{B}$ at a

Abbreviations: DOC $=$ deoxycholate; DTT $=$ dithiothreitol; HEPES $=\mathrm{N}$-2-hydroxyethylpiperazine-N'-2-ethane sulfonic acid; HKM = HEPES-K-Mg-acetate buffer (see 2.1.); Met = methionine; SDS-PAGE = Sodium dodecyl sulfate polyacrylamide gel electrophoresis; TCA = trichloracetic acid. 
concentration of $1 A_{260}$ unit/10 $\mu$ land stored in liquid nitrogen.

\subsection{Polysome isolation}

Detached polysomes were prepared from 20 day old Bomi barley endosperm as described previously (4).

\subsection{Electron microscopy of the material con- tained in density gradient bands I and II}

The pellet obtained after the sucrose wash of bands I and II (see section 2.3.) was fixed in HKM buffer B containing $2 \%$ glutaraldehyde at $0^{\circ} \mathrm{C}$ and pelleted by centrifugation at 105,000 $\mathrm{g}_{\mathrm{av}}$ in a Beckman $50 \mathrm{Ti}$ rotor for $30 \mathrm{~min}$. The pellet was resuspended in 2.3 drops of $45^{\circ} \mathrm{C}$ HKM buffer B containing $2 \%$ agar and then immediately applied to a precooled microscope slide. The solidified agar was then cut into 1 $\mathrm{mm}^{3}$ cubes and the embedded material postfixed with $2 \% \mathrm{OsO}_{4}$ in $\mathrm{HKM}$ buffer $\mathrm{B}$ for $1 \mathrm{~h}$. The fixed cubes were then washed in water and stained with $0.5 \%$ uranylacetate for $2 \mathrm{~h}$ at $20^{\circ} \mathrm{C}$. Dehydration, final embedding in epoxyresin and sectioning were performed as described earlier (11).

\subsection{Cell-free protein synthesizing system}

An S-30 wheat-germ extract was prepared as described by MARCU and DUDOCK (15) and used for cell-free protein synthesis.

The standard reaction mixture for incorporation of amino acids into proteins contained $5 \mu \mathrm{l} \mathrm{S-30} \mathrm{wheat-germ} \mathrm{extract,} \mathrm{1-2} \mathrm{A}_{260}$ unit of rough microsomes or polysomes, $1 \mathrm{mM}$ ATP, $200 \mu \mathrm{M}$-GTP, $25 \mathrm{~mm}$-HEPES pH 7.6, 2.0 $\mathrm{mM}-\mathrm{Mg}$ acetate, $100 \mathrm{mM}-\mathrm{K}$ acetate, $10 \mu \mathrm{Ci}{ }^{35} \mathrm{~S}$ Met (specific activity approx. $900 \mathrm{mCi} / \mathrm{mmol}$ ) and $20 \mu \mathrm{M}$ of each of the other 19 amino acids in a final volume of $50 \mu \mathrm{l}$.

The reaction mixture was incubated at $27^{\circ} \mathrm{C}$ for $60 \mathrm{~min}$, and to measure the incorporation of ${ }^{35} \mathrm{~S}-\mathrm{Met}$ into TCA precipitable proteins $5 \mu \mathrm{l}$ aliquots were pipetted onto Whatman $3 \mathrm{MM}$ filter paper discs impregnated with $10 \%$ TCA. The discs were heated to $100^{\circ} \mathrm{C}$ for $10 \mathrm{~min}$ in $10 \%$ TCA containing $10 \mathrm{mM}-\mathrm{Met}$, washed in $5 \%$
TCA and dried by successive dipping in ethanol (96\%), ethanol:diethylether $1: 1$, and diethylether. The radioactivity precipitated on the discs was counted in a toluene based scintillator, containing $0.4 \%$ omnifluor (New England Nuclear), in a Beckman LS $3155 \mathrm{~T}$ liquid scintillation spectrometer.

\subsection{SDS-PAGE and fluorography of polypep- tides synthesized in the cell-free system}

Cell-free protein synthesis was terminated by the addition of $1 \mathrm{ml} \mathrm{10 \%} \mathrm{TCA,} 10 \mathrm{mM}-\mathrm{Met}$ and the hordein translation products were extracted into $55 \%$ isopropanol containing $2 \%$ mercaptoethanol, $10 \mathrm{mM}$-Met, $10 \mathrm{mM}$-EDTA and $100 \mu \mathrm{g} / \mathrm{ml}$ carrier hordein. After removal of insoluble proteins by centrifugation, the isopropanol extracts containing the hordeins were dried down and prepared for electrophoresis. The extracts were suspended in $20 \mu \mathrm{l} 0.1$ M-Tris base, $1 \mu \mathrm{l} 1 \%$ bromophenol blue, $20 \mu 1$ $30 \%$ sucrose: $5 \%$ SDS and $5 \mu \mathrm{l} 0.1 \mathrm{M}$-DTT, and boiled for $1 \mathrm{~min} .10 \mu \mathrm{l}$ of $0.2 \mathrm{M}$-iodoacetamide were added to each sample $2 \mathrm{~h}$ prior to electrophoresis. Electrophoresis was performed according to the procedure of CHUA and BENNOUN (8). Native ${ }^{14} \mathrm{C}$-labelled hordeins were co-electrophoresed as markers.

The gels were then prepared for fluorography as described by BONNER and LASKEY (3), and exposed to RP Royal X-omat film (Kodak) at $-70^{\circ}$ for 4-6 days, and then developed.

\subsection{Preparation of in vivo ${ }^{14} \mathrm{C}$-labelled hordeins}

Five barley spikes were cut $10 \mathrm{~cm}$ below the ear 14 days after anthesis. The spikes were placed in a solution of $200 \mu \mathrm{Ci}\left[\mathrm{U}{ }^{14} \mathrm{C}\right]$-sodium acetate in $1 \mathrm{ml}$ water. After the acetate had been taken up, the spikes were left for 14 days in a nutrient solution. The seeds were then collected and homogenized in $50 \mathrm{ml} 55 \%$ isopropanol with $2 \%$ mercaptoethanol. After stirring for $1 \mathrm{~h}$, the hordein extract was recovered by centrifugation at $10,000 \mathrm{~g}$ for 10 $\min$. The extract was then dialyzed overnight against water and freeze dried. Carrier hordeins were isolated in a similar way from mature nonradioactive seeds. 

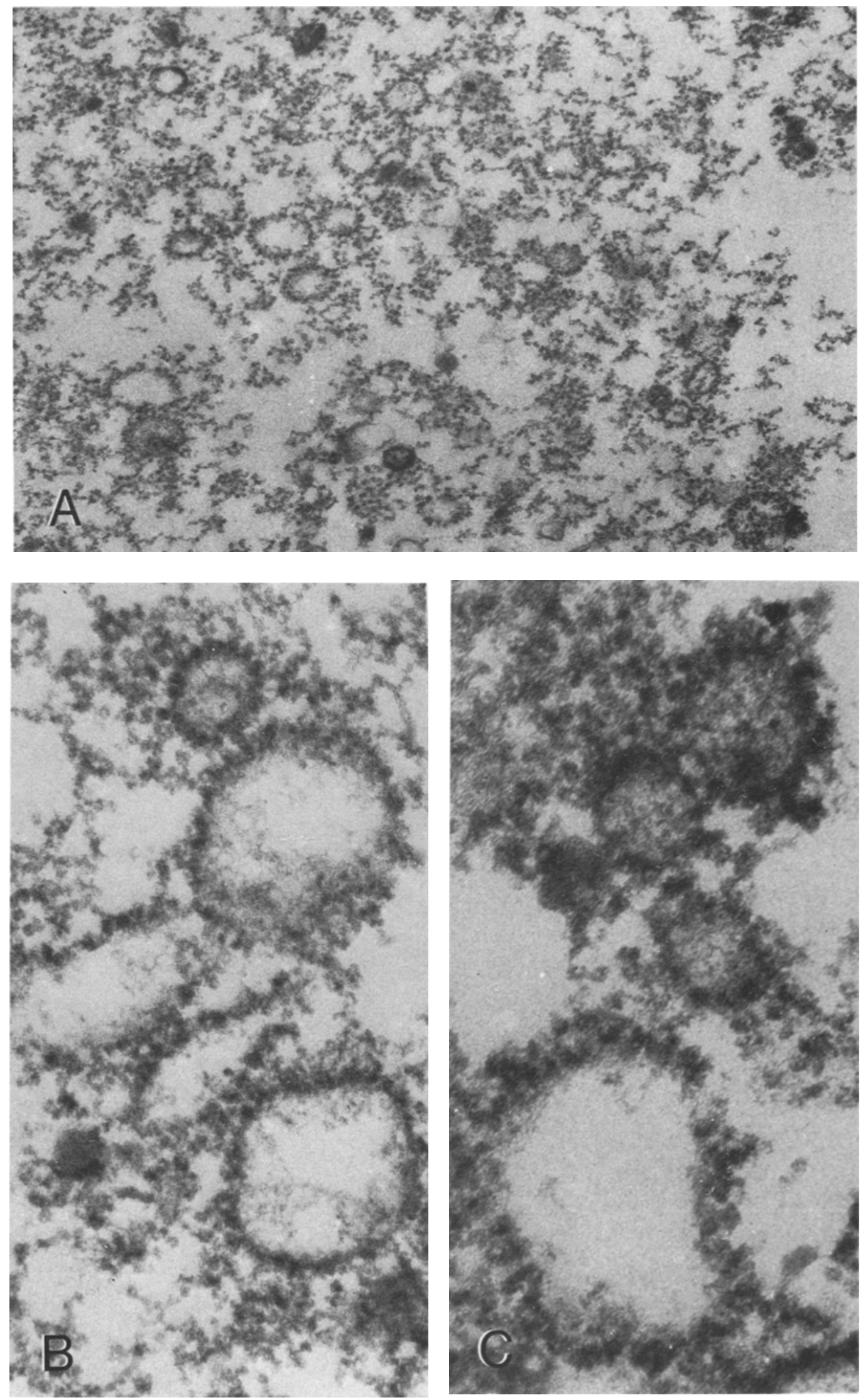


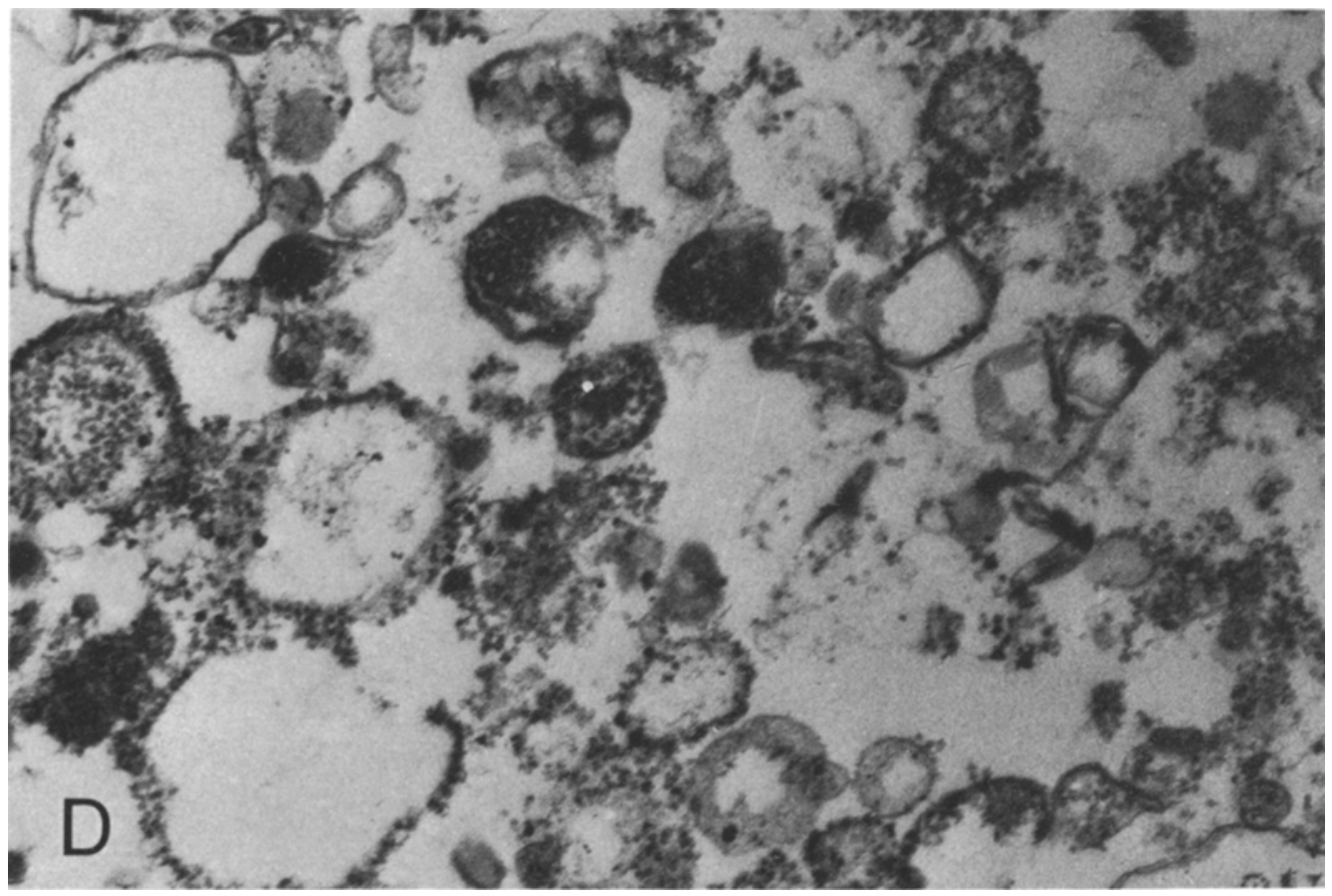

Figure 1. Rough microsomes from Bomi barley endosperm. Rough microsomes were prepared from 20 day old Bomi barley endosperm by homogenizing tissue in HKM buffer A. The homogenate was centrifuged at $500 \mathrm{~g}$ for $10 \mathrm{~min}$ in a Sorvall SS-34 rotor. The supernatant was then centrifuged at $37,000 \mathrm{~g}$ for $10 \mathrm{~min}$ in the same rotor to pellet the endosperm membrane fraction. The pellet was resuspended in $10 \mathrm{ml}$ of $2.26 \mathrm{M}$-sucrose and overlaid with $10 \mathrm{ml}$ portions of $1.75,1.5$, and $0.2 \mathrm{M}$-sucrose, all containing HKM buffer B, and centrifuged at $96,000 \mathrm{gav}$ for $16 \mathrm{~h}$ in a Beckman SW 27 rotor. The material banding at the 1.75-2.26 M-sucrose interface (band I) and at the 1.5-1.75 M-sucrose interface (band II) was isolated, fixed, stained, embedded and sectioned for electron microscopy. A, B, C are from band I and D from band II. Magnification: A, $\times 43,500 ;$ B, $\times 106,000 ;$ C, $\times 129,000$; $\mathrm{D}, \times 43,500$.

\section{RESULTS}

\subsection{Isolation and characterization of barley endosperm rough microsomes}

Rough membrane fractions were obtained from Bomi endosperm, banding at two positions on a discontinuous sucrose gradient, namely at the interfaces of $1.5-1.75 \mathrm{M}$ (band II) and 1.75-2.26 $\mathrm{M}$ (band I). The yields are shown in Table 1 .

Electron microscopy of sections through a suspension of the material in band I revealed a high content of microsomes i.e. endoplasmic reticulum derived vesicles with polysomes attached to their outer surface (Figure 1A). Some electron dense material was present inside the microsomes close to the membrane (Figures 1B and $\mathrm{C}$ ).
Electron microscopy of the material in band II showed a mixed population of microsomes, smooth membrane vesicles and membrane vesicles containing ribosomes (Figure 1D). Since

\section{Table I}

Yield of rough microsomes from Bomi barley endosperm. Rough microsomes from 20 day old Bomi barley endosperm were isolated as described under Materials and methods (2.3.). The ratio of the absorption at 260 $\mathrm{nm}$ to that at $280 \mathrm{~nm}$ is lower than the value of 1.8 found with purified polysomes (4). This is expected because of the protein absorption contributed by the membranes.

\begin{tabular}{|c|c|c|}
\hline & Yield & Ratio \\
\hline & A 260 units/10 spikes & $\mathrm{A}_{260} / \mathrm{A}_{280}$ \\
\hline Band I & 43.5 & 1.24 \\
\hline Band II & 36.0 & 1.22 \\
\hline
\end{tabular}


Table II

Cell-free protein synthesis directed by rough microsomes from Bomi barley endosperm. Rough microsomes from 20 day old Bomi barley endosperm were isolated and assayed in the standard reaction mixture as described under Materials and methods (2.6.).

\begin{tabular}{lccc}
\hline Microsome Fraction & S-30 Wheat-germ & cpm/A260 unit & $\begin{array}{c}\text { Stimulation over } \\
\text { wheat-germ control }\end{array}$ \\
\hline Band I & + & 602,900 & 5.9 \\
Band II & + & 605,000 & 5.9 \\
0 & + & 102,000 & \\
Band I & 0 & 50,900 & \\
Band II & 0 & 35,800 &
\end{tabular}

microsomes were present in band II, it was also studied as a template in the in vitro incubations.

3.2. Cell-free protein synthesis with barley endosperm rough microsomes

The rough microsomes isolated from Bomi endosperm were incubated in the standard reaction mixture at $27^{\circ} \mathrm{C}$ for $40 \mathrm{~min}$. The in-

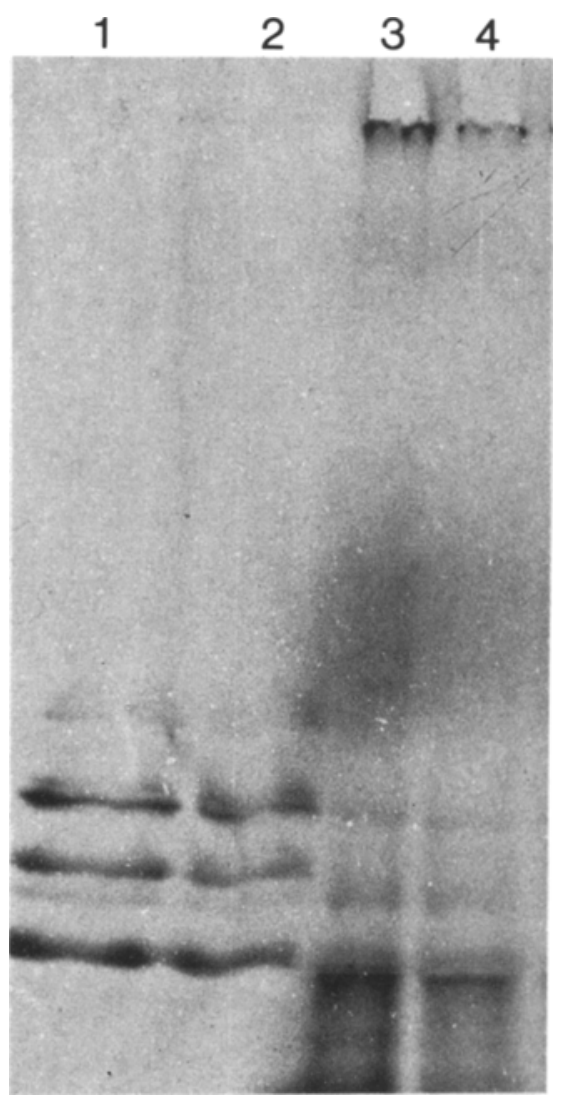

corporation of ${ }^{35} \mathrm{~S}-\mathrm{Met}$ into hot $10 \%$ TCA insoluble material in the presence or absence of S-30 wheat-germ extract was determined (Table II).

The addition of membrane-bound polysomes, associated with the two rough microsome fractions of Band I and II, to the wheat-germ cell-free system caused a 6 fold stimulation of protein synthesis. Translation on the membrane-bound polysomes was largely dependent on the wheat-germ extract.

The in vitro translation products were analysed by SDS-PAGE and fluorography. In order to exclude all but the hordein mRNA translation products, the $10 \%$ TCA precipitates of the reaction mixtures were extracted with $55 \%$ isopropanol containing $10 \mathrm{mM}$-EDTA and $100 \mu \mathrm{g} / \mathrm{ml}$ carrier hordeins. Trial extractions of in vivo ${ }^{14} \mathrm{C}$-labelled hordeins revealed that over $90 \%$ of the hordeins could be recovered in an isopropanol extract after TCA precipitation. The fluorogram seen in Figure 2 shows the separation of native hordein in tracks 1 and 2.

Figure 2. SDS-PAGE of 55\% isopropanol soluble translation products of rough microsomes from Bomi barley endosperm. Cell-free protein synthesis with rough microsomes from 20 day old Bomi barley endosperm and electrophoresis and fluorography of the products were as described under Materials and methods (2.6., 2.7.). The fluorogram shows in vivo ${ }^{14} \mathrm{C}$-labelled hordein marker, track $1 ; 55 \%$ isopropanol soluble hordein marker extracted from TCA precipitate, track 2; translation products of rough microsomes from $2 A_{260}$ units, track 3 and 1 $\mathrm{A}_{260}$ unit, track 4. 
The 55\% isopropanol solubilized hordeins in track 2 were derived from a TCA precipitate, thereby confirming the reliability of this isolation proceduce. Tracks 3 and 4 contain the translation products from band I rough microsomes at two concentrations. Most of the native hordein polypeptides are represented among the in vitro translation products. The preponderance of low molecular weight polypeptides is probably due to premature chain termination and the extraction of low molecular weight wheat-germ translation products.

\subsection{Optimization of cell-free protein synthesis with barley endosperm rough microsomes}

In order to maximise the efficiency of in vitro protein synthesis we assessed certain parameters in the procedure by measuring the incorporation of ${ }^{35} \mathrm{~S}-\mathrm{Met}$ into hot $10 \%$ TCA insoluble material in the presence of band $\mathrm{I}$ rough microsomes. The time-course of in vitro protein synthesis performed at $27^{\circ} \mathrm{C}$ in the standard reaction mixture (Figure $3 \mathrm{~A}$ ), shows a significant decline in the rate of synthesis after $20 \mathrm{~min}$ and by $80 \mathrm{~min}$ a slight loss of product is observed. It is probable that the decline in synthesis rate is partially due to a depletion of reaction mixture components, in particular the energy generating system, and partially to proteolysis of the translation products. Incubations of 60 min were considered optimal for subsequent assays.

Figure 3B shows a rise in protein synthesis with increasing concentrations of rough microsomes per assay. A concentration of 1 $A_{260}$ unit/assay was selected for subsequent experiments.

In vitro protein synthesis using the wheatgerm cell-free system has been found to show a sharp magnesium response $(15,17)$. However, unlike the translation of mRNA associated with free or detached polysomes, the rough microsomes in barley (Figure 3C) appear to be little sensitive to magnesium concentration. It is possible that the ion-binding capacity of membranes enables them to perform a magnesium buffering role.
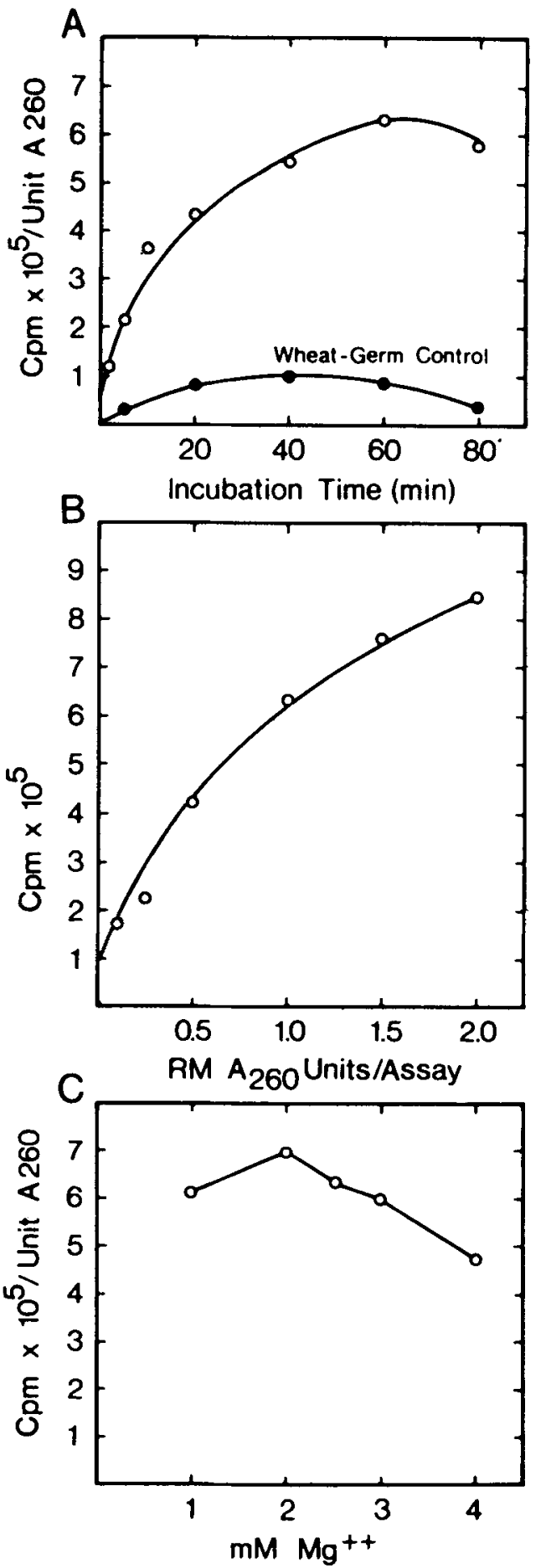

Figure 3. Optimization of cell-free protein synthesis directed by rough microsomes from Bomi barley endosperm. Rough microsomes (band I) from 20 day old Bomi barley endosperm were isolated and assayed in the standard reaction mixture as described under Materials and methods. 


\subsection{Membrane transport of hordeins synthesized on barley endosperm rough microsomes}

According to the signal hypothesis (1) for the synthesis of vectorially discharged proteins, the translation of their mRNA on membranebound polysomes yields nascent chains which are transported through the membrane as an integral part of their synthesis. Thus, when cellfree protein synthesis is directed by rough microsomes, the products are transferred into the microsomal cisternae, a phenomenon best demonstrated by their protection from proteolytic attack $(7,9)$.

Conditions suitable for the proteolysis of native hordeins were first investigated using in vivo ${ }^{14} \mathrm{C}$-labelled hordeins. $100 \mu \mathrm{g}$ each of chymotrypsin and trypsin were added to $50 \mu \mathrm{l}$ of a solution containing $100 \mu \mathrm{g}{ }^{14} \mathrm{C}$-hordeins and 5

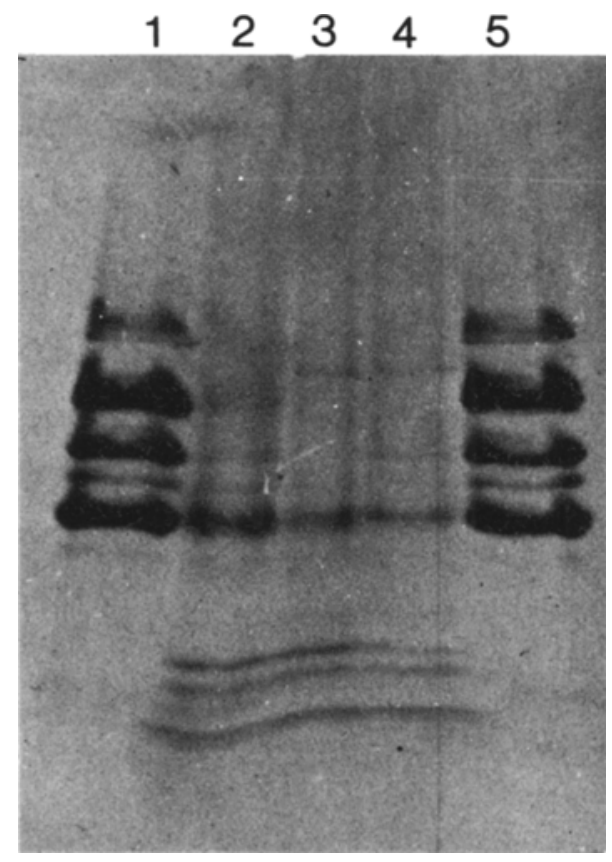

Figure 4. SDS-PAGE of native hordeins after proteolytic treatment. In vivo ${ }^{14} \mathrm{C}$-labelled hordein $(100 \mu \mathrm{g})$ was treated with $100 \mu \mathrm{g}$ each of chymotrypsin and trypsin at $2^{\circ} \mathrm{C}$, in the presence or absence of S-30 wheat-germ extract. The products were analysed by electrophoresis and fluorography as described under Materials and methods (2.7.). The fluorogram shows ${ }^{14} \mathrm{C}$-hordein marker, tracks 1,$5 ;{ }^{14} \mathrm{C}$-hordein with S-30 wheat-germ after 40 and 180 min proteolysis, tracks 2,$3 ;{ }^{14} \mathrm{C}$-hordein after $180 \mathrm{~min}$ proteolysis, track 4 . $\mu$ S-30 wheat-germ extract, and incubated at $2^{\circ} \mathrm{C}$ for 40 or $180 \mathrm{~min}$. Chymotrypsin treatment of the cell-free system is performed at $2^{\circ} \mathrm{C}$ to prevent further protein synthesis. The reaction was terminated with $10 \%$ TCA and the products analysed by SDS-PAGE and fluorography. The fluorogram (Figure 4) shows a partial degradation of hordeins after 40 and 80 min (tracks 2 and 3 respectively), but it was subsequently observed that chymotrypsin alone, at concentrations as low as $10 \mu \mathrm{g} /$ assay, hydrolysed the hordeins after $120 \mathrm{~min}$ incubation. It should be noted that three groups of large peptide fragments are prominent among the cleavage products of hordein proteolysis. One may infer a degree of uniformity of composition among the hordein polypeptides from the limited points of proteolytic cleavage.

The accessibility of hordeins, synthesized in vitro on detached polysomes and rough microsomes, to proteolytic attack could then be investigated, measuring the TCA precipitable translation products remaining after chymotrypsin treatment. Since the background count in the precipitates, contributed by the wheatgerm translation products, is lost after chymotrypsin treatment (not shown) it has been subtracted from the untreated assays. A greater extent of proteolysis was found for proteins synthesized on detached polysomes as compared to those made on rough microsomes from band I or band II (Table III). While at first sight the polysomes may appear to afford some protection to their nascent polypeptides, it should be appreciated that a significant proportion of the larger cleavage products may be precipitated by TCA. This conclusion is fully supported by analysis of the chymotrypsin-treated translation products by SDS-PAGE and fluorography. The fluorogram (Figure 5) shows the hordeins synthesized by rough microsomes (band II, track 1; band I, track 3) and by detached polysomes (track 9), and after their respective treatment with 5 or $10 \mu \mathrm{g}$ chymotrypsin/assay (tracks 2,4 , 5,10 and 11). Here there is no evidence of protection of the hordeins synthesized on detached polysomes (tracks 10,11), and release of larger cleavage products can be seen close to the tracking dye. However, the hordeins synthesized on rough microsomes from both bands 
I and II (tracks 2, 4, 5), were afforded significant protection from proteolysis. The vectorial discharge of hordeins synthesized on rough microsomes into their lumen is further indicated by the ability of membrane-solubilizing detergents to expose the hordeins to proteolytic attack. Triton X-100 (1\%) and DOC (0.05$0.5 \%$ ), detergents, which did not impair the proteolysis of polysomal translation products (tracks 12, 13), destroyed the microsomal protection of transported hordeins (tracks 6, 7, 8).

The absence of wheat-germ translation products in track 14 (Figure 5) confirms the hordein selectivity of $55 \%$ isopropanol extraction for hordeins.

\section{DISCUSSION}

\subsection{Isolation of rough microsomes}

The electron micrographs of the microsomal fraction, designated as band $I$, contained microsomes and what could be interpreted as free polysomes (Figures 1A-C). The method applied for the preparation of the microsomal fraction makes the presence of free polysomes in this fraction highly unlikely, since only membrane-bound polysomes are isolated by the initial $37,000 \mathrm{~g}$ spin. If polysomes are detached subsequently they would be pelleted during the flotation step involving centrifugation at 96,000 $\mathrm{g}_{\mathrm{av}}$. The ribosomes not visibly attached to microsomal membranes in Figures $1 \mathrm{~A}-\mathrm{C}$ are therefore interpreted as being members of microsomal polysomes which are not yet in contact with the microsomal membrane. In some cases electron dense material is observed adhering to the inner surface of the microsomal membranes (Figures $1 \mathrm{~B}, \mathrm{C}$ ). It is tempting to suggest that this material represents vectorially discharged polypeptides.

\subsection{Cell-free synthesis of barley endosperm proteins}

Hordeins are hydrophobic proteins, deposited as protein bodies bounded by a tonoplast in the developing barley endosperm $(11,16)$, and whose synthesis is primarily directed by membrane-bound polysomes (4). In many animal cells, particularly those from secretory tissues, the synthesis of exported proteins on membrane-bound polysomes is closely associated with their subsequent excretion. Techniques developed to demonstrate the concommitent synthesis and vectorial discharge of animal proteins in vitro, have been applied in the study of hordein synthesis on barley endosperm rough microsomes. These include the use of proteolytic enzymes to detect the distribution

\section{Table III}

Cell-free synthesis of proteins on rough microsomes and detached polysomes from Bomi barley endosperm and their accessibility to proteolytic attack. Rough microsomes and polysomes from 20 day old Bomi barley endosperm were isolated and assayed in the standard reaction mixture as described under Materials and methods (2.6.). TCA precipitable translation products remaining after $2 \mathrm{~h}$ chymotrypsin treatment $(10 \mu \mathrm{g} /$ assay $)$ were measured.

\begin{tabular}{ccccc}
\hline & $\begin{array}{c}\text { Chymotrypsin } \\
\text { treated }\end{array}$ & $\begin{array}{c}\text { Detergent } \\
\text { treated }\end{array}$ & cpm/assay ${ }^{+}$ & $\begin{array}{c}\text { per cent } \\
\text { proteolysis }\end{array}$ \\
\hline Detached polysomes & 0 & 0 & 708,600 & 36 \\
- & + & 0 & 451,200 & 40 \\
- & + & $1 \%$ Triton X-100 & 428,800 & 40 \\
Rough microsomes & + & $0.50 \%$ DOC & 426,400 & 19 \\
band I & 0 & 0 & 126,800 & 37 \\
- & + & 0 & 102,700 & 48 \\
- & + & $1 \%$ Triton X-100 & 79,500 & 34 \\
- & + & $0.05 \%$ DOC & 65,900 & 83,370 \\
band II & + & $0.50 \%$ DOC & 166,400 & 29 \\
\hline
\end{tabular}

+ A wheat-germ background count of $80,000 \mathrm{cpm}$ was subtracted from all untreated samples. 


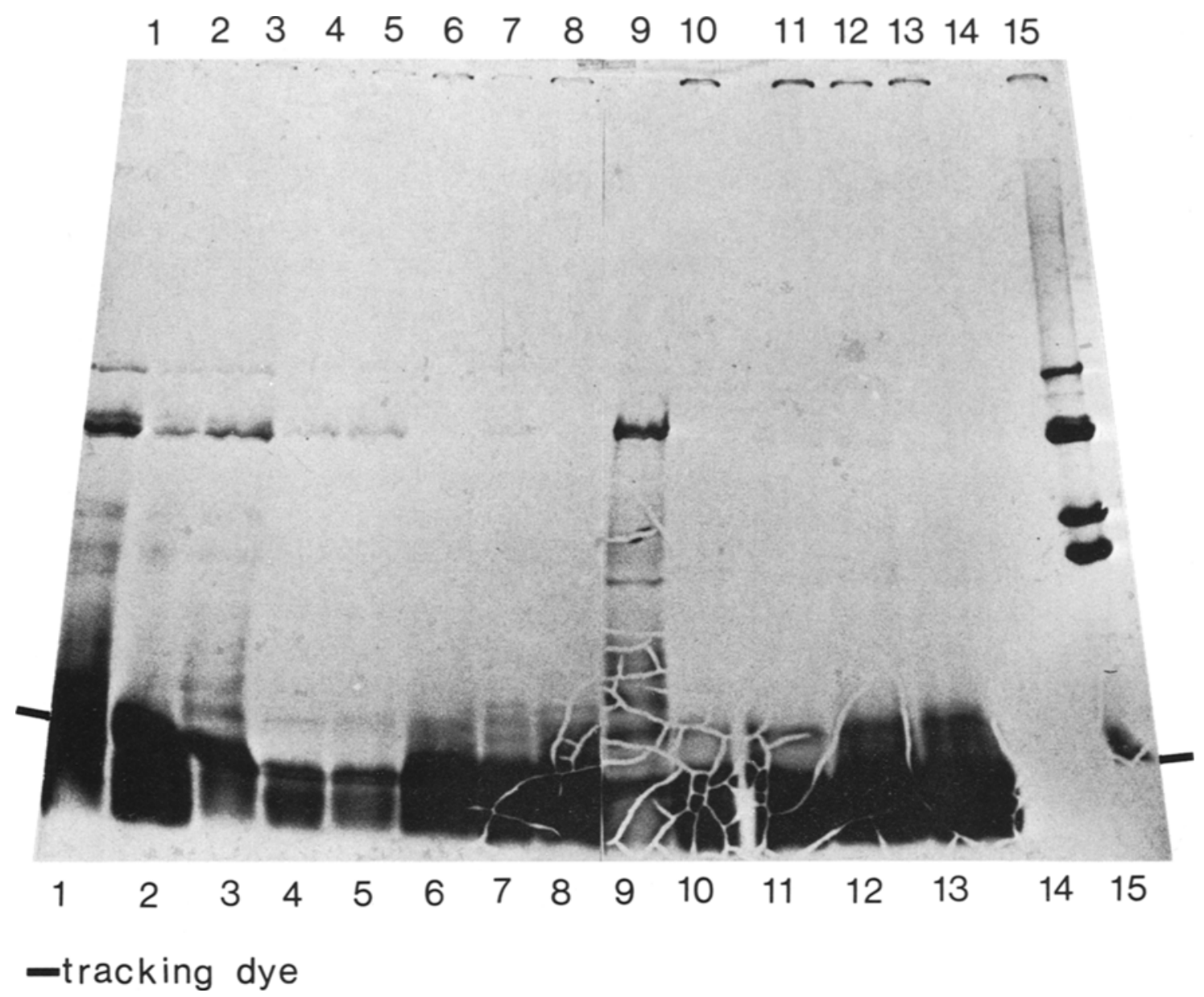

of translation products of membrane-bound polysomes between the medium and the microsomal lumen. When cell-free protein synthesis was followed by a two hour chymotrypsin treatment af $2^{\circ} \mathrm{C}$, the hordeins synthesized by detached polysomes were extensively degraded, while the hordeins synthesized by rough microsomes were largely preserved. Further confirmation of the vectorial discharge of hordeins synthesized on rough microsomes was gained from the results of chymotrypsin treatment in the presence of membrane-solubilizing detergents.

Concentrations of DOC $(0.05 \%)$ sufficient only to cause membrane leakiness, as against complete dissassembly, have been determined for rat liver microsomes (12). The pores thus created in the microsomes gave access to proteolytic enzymes which degraded polypeptides released into the microsomal cavity. The location of in vitro synthesized hordeins within the microsomal cavity and not in the membrane, was similarly indicated in the present work by their exposure to proteolytic attack by $0.05 \%$ DOC.

Other examples of protein membrane transport in plant cells are limited, but the synthesis of the chloroplast protein ribulose-1,5bisphosphate carboxylase, whose small subunit is encoded in the nuclear genome, has received particular attention. In both Pisum sativum (10) and Chlamydomonas reinhardtii (9) the small subunit is synthesized on cytoplasmic polysomes and subsequently transported into the chloroplast. The primary translation product has a higher molecular weight indicating a 
Figure 5. SDS-PAGE of 55\% isopropanol soluble translation products of rough microsomes and polysomes from Bomi barley endosperm after proteolytic treatment. Cell-free protein synthesis was performed with rough microsomes and polysomes prepared from 20 day old Bomi barley endosperm. The $55 \%$ isopropanol soluble translation products remaining after $2 \mathrm{~h}$ chymotrypsin treatment at $2^{\circ} \mathrm{C}$ were analysed by electrophoresis and fluorography as described under Materials and methods (2.7.). The fluorogram shows translation products after the following treatments.

\begin{tabular}{|c|c|c|c|}
\hline & Template & Chymotrypsin & Detergent \\
\hline Track 1 & $\begin{array}{l}\text { rough microsomes } \\
\text { (band II) }\end{array}$ & 0 & 0 \\
\hline Track 2 & - & $10 \mu \mathrm{g}$ & 0 \\
\hline Track 3 & $\begin{array}{l}\text { rough microsomes } \\
\text { (band I) }\end{array}$ & 0 & 0 \\
\hline Track 4 & - & $5 \mu \mathrm{g}$ & 0 \\
\hline Track 5 & - & $10 \mu \mathrm{g}$ & 0 \\
\hline Track 6 & - & $10 \mu \mathrm{g}$ & $1 \%$ Triton X-100 \\
\hline Track 7 & - & $10 \mu \mathrm{g}$ & $0.05 \%$ DOC \\
\hline Track 8 & - & $10 \mu \mathrm{g}$ & $0.50 \% \mathrm{DOC}$ \\
\hline Track 9 & detached polysomes & 0 & 0 \\
\hline Track 10 & - & $5 \mu \mathrm{g}$ & 0 \\
\hline Track 11 & - & $10 \mu \mathrm{g}$ & 0 \\
\hline Track 12 & - & $10 \mu \mathrm{g}$ & $1 \%$ Triton X-100 \\
\hline Track 13 & - & $10 \mu \mathrm{g}$ & $0.50 \% \mathrm{DOC}$ \\
\hline Track 14 & wheat-germ S-30 & 0 & 0 \\
\hline Track 15 & $\begin{array}{l}\text { Marker consisting of } \\
\text { native } 14 \mathrm{C} \text {-hordein }\end{array}$ & & \\
\hline
\end{tabular}

signal sequence for membrane transport. The extra amino acid sequence is absent from the small subunits isolated from the chloroplasts $(9$, 10). However, the mechanism of polypeptide transport involved is likely to be different from that envisaged for polypeptides transferred into the lumen of the endoplasmic reticulum, owing to the independence of the synthesis of the small subunit and its subsequent transport.

In the present paper it has been shown that nascent hordein polypeptides are transferred into the lumen of the endoplasmic reticulum of barley endosperm. The next task is to determine whether the newly synthesized hordein chains contain a signal sequence of amino acids.

\section{ACKNOWLEDGEMENTS}

We would like to thank professor D. voN WETTSTEIN for valuable discussions and for helpful criticism during the preparation of the manuscript. We are grateful to BIBI STAMPE ANDERSEN and JEAN SAGE for their skillful technical assistance. VERENA CAMERON-M ILLS has been supported by a Leverhulme European Studentship and the Royal Society European Programme Fund. ANDERS B RANDT acknowledges the receipt of a fellowship from the Ris $\emptyset$ National Laboratory. The work was supported by a grant from the USPHS, National Institutes of Health (GM-22051) to professor D. vON WETTSTEIN.

\section{REFERENCES}

1. Blobel, G. \& B. Dobberstein: Transfer of proteins across membranes. I. Presence of proteolytically processed and nonprocessed nascent immunoglobulin light chains on membranebound ribosomes of murine myeloma. J. Cell Biol. 67, 835-851 (1975)

2. Blobel, G. \& B. Dobberstein: Transfer of proteins across membranes. II. Reconstitution of functional rough microsomes from heterologous components. J. Cell Biol. 67, 852-862 (1975)

3. BONNER, W. M. \& R. A. LASKEY: A film detection method for tritium-labelied proteins and nucleic acids in polyacrylamide gels. Eur. J. Biochem. 46, 83-88 (1974) 
4. BRANDT, A. \& J. INGVERSEN: In vitro synthesis of barley endosperm proteins on wild type and mutant templates. Carlsberg Res. Commun. 41, 312320 (1976)

5. Burke, G. T. \& C. M. Redman: The distribution of radioactive peptides synthesized by polysomes and ribosomal subunits combined in vitro with microsomal membranes. Biochem. Biophys. Acta 299, 312-324 (1973)

6. BURR, B. \& F. A. BURR: Zein synthesis in maize endosperm by polyribosomes attached to protein bodies. Proc. Nat. Acad. Sci. USA 73, 515-519 (1976)

7. Christianson, D. D., U. Khoo, H. C. Nielsen \& J. S. WALL: Influence of opaque-2 and floury-2. genes on formation of proteins in particulates of corn endosperm. Plant Physiol. 53, 851-855 (1974)

8. Chua, N.-H. \& P. Bennoun: Thylakoid membrane polypeptides of Chlamydomonas reinhardtii wild type and mutant strains deficient in photosystem II reaction center. Proc. Nat. Acad. Sci. USA 72, 2175-2179(1975)

9. Dobberstein, B., G. Blobel \& N.-H. Chua: In vitro synthesis and processing of a putative precursor for the small subunit of ribulose-1,5bisphosphate carboxylase of Chlamydomonas reinhardtii. Proc. Nat. Acad. Sci. USA 74, $1082-$ 1085 (1977)

10. Highfield, P. E. \& R. J. Ellis: Synthesis and transport of the small subunit of chloroplast ribulose bisphosphate carboxylase. Nature 271, 420-424 (1978)
11. INGVERSEN, J.: Structure and composition of protein bodies from wild-type and high-lysine barley endosperm. Hereditas 81, 69-76 (1975)

12. Kreibich, G. \& D. D. Sabatini: Microsomal membranes and the translational apparatus of eukaryotic cells. Fed. Proc. Fed. Amer. Soc. Exp. Biol. 32, 2133-2138 (1973)

13. Larkins, B. A., C. E. Bracker \& C. Y. TSaI: Storage protein synthesis in maize. Isolation of zein-synthesizing polyribosomes. Plant Physiol. 57, 740-745 (1976)

14. Luthe, D. S. \& D. M. Peterson: Cell-free synthesis of globulin by developing oat (Avena sativa). Plant Physiol. 59, 836-841 (1977)

15. Marcu, K. \& B. Dudock: Characterization of a highly efficient protein synthesizing system from commercial wheat germ. Nucleic Acids Res. 1, 1385-1397 (1974)

16. MUNCK, L. \& D. VON WETTSTEIN: Effects of genes that change the amino acid composition of barley endosperm. In: Genetic improvement of seed proteins. Proc. of a workshop 18-20 March 1974. National Academy of Sciences, Washington D. C. pp. 71-82 (1976)

17. Roberts, B. E. \& B. M. Paterson: Efficient translation of tobacco virus RNA in a cell-free system from commercial wheat germ. Proc. Nat. Amer. Soc. USA 70, 2330-2334 (1973)

18. Shore, G. C. \& R. HARris: Fate of polypeptides synthesized on rough microsomal vesicles in a messenger-dependent rabbit reticulocyte system J. Cell Biol. 74, 315-321 (1977) 